\title{
AYURVEDA FOR PREGNANT WOMEN DURING COVID-19 ERA - A REVIEW
}

\author{
Dr. Supriya $B^{1}$, Dr. Savita S. Patil ${ }^{2}$ \\ ${ }^{I} P G$ Scholar Dept. of PTSR, SSCASR, Bengaluru \\ ${ }^{2}$ Professor \& HOD Dept. of PTSR, SSCASR, Bengaluru
}

Article DOI: https://doi.org/10.36713/epra8760

DOI No: 10.36713/epra8760

\begin{abstract}
The Novel corona virus disease (COVID-19) is highly communicable viral infection caused by SARS-CoV 2. WHO mentions that pregnant women or recently pregnant women seem to have an increased risk of developing severe COVID-19. Due to physiological changes in the body and immune system, pregnant women can be badly affected by respiratory infections. It is therefore important that they take precautions to protect themselves against COVID-19. Overall, 10\% of pregnant women suffered from COVID-19. Ayurveda mentions Garbhini paricharya (antenatal care of the pregnant) which recommends ahara (dietary regimen) and vihara (specific activity for physical, emotional and mental wellbeing) that is required for the safe motherhood and healthy progeny. Here is an attempt to understand how Garbhini paricharya helps in preventing corona.
\end{abstract}

KEY WORDS: Garbhini paricharya, COVID-19, Pregnancy

\section{INTRODUCTION}

Ayurveda is a "science of life" which is having explanation for all the queries.

As Dridabala mentions,

यदिहास्ति तदन्यत्र यन्नेहास्ति न तत् क्वचित् ।

That is whatever mentioned in Ayurveda shastra is present everywhere and whatever is not mentioned is not present anywhere. Ayurveda has not mentioned diseases like COVID-19. However, they explain the things briefly which should be understood using Arthapatti tantrayukti.

Acharya Sushruta quotes,

\section{स्वस्थस्य स्वास्थ्य रक्षणं आतुरस्य विकार प्रशमनम |}

Which means the aim of the Ayurveda is to cure the disease of the diseased individual and to maintain the health of a healthy individual by following the paricharya's mentioned. ${ }^{1}$

As garbhini is sukumara and abala, she is easily prone for infections. Acharyas have priorly mentioned certain norms to be followed by the garbhini, so that she can prevent the forthcoming diseases.
Garbhini paricharya mentioned by our acharyas refers to antenatal care given to the pregnant women. Various ahara, vihara and aushadhas in the form of do's and dont's are explained for maintenance of the physical and mental health of the pregnant women.

\section{MATERIALS AND METHODS}

Review regarding Garbhini paricharya was done from ayurvedic \& modern text books, journals, internet sources.

\section{DISCUSSION}

Dravyas used in garbhini paricharya majorly includes ksheera (milk), ghrita (ghee) and madhura varga dravyas which acts as rasayana (immunomodulators).

- Bala - owns properties like balya (improves strength), kshayahara (relieves emaciation), ojovardhaka (improves immunity). It is also proven to have antioxidant, anti-inflammatory, anti-pyretic and anti-microbial properties. ${ }^{2}$ 


\section{EPRA International Journal of Research and Development (IJRD)}

- Yashtimadhu - contains phytochemical such as flavonoids like glycyrrhin, glabridin that has been proved to have anti-viral activity against the SARS corona virus. $^{3}$

- Ashwagandha - it is observed that one of the compound present in Ashwagandha called withanone is quite effective and useful in blocking and weakening the structure of $\mathrm{M}^{\text {pro }}$ (enzyme, which plays a key role in viral replication and transcription). ${ }^{4}$

- Amalaki - Amalaki is balavardhini (improves strength and immunity), rasayani (immunomodulator) and proved to have anti-microbial activity. ${ }^{5}$

- Shatavari - anti-oxidant, antiinflammatory, anti-microbial and potential immunomodulatory properties. $^{6}$

- Palasha - mentioned in the $1^{\text {st }}$ month of garbhini paricharya by Vagbhata I, has an unique krimighna(anti-viral) properties. ${ }^{7}$

- Jeevaniya gana dravyas - mentioned by Acharya Charaka in sutrasthana $4^{\text {th }}$ chapter owns the properties of balya and rasayana

Vihara:

- Abhyanga - it helps in healing and promoting health. It makes the garbhini balavan and traps the entry of foreign body.

- Garbhini snana - Acharyas have mentioned the use of certain drugs for snana which includes bilva (Agle mermelos), karpasa (Gossypium herbaceum), agnimantha (Clerodendrum phlomidis), jatamamsi (Nardostachys jatanansi), eranda patra (Ricinis comunis) which owns anti-viral properties. Snana is also malapaha (which removes the mala).

- Manidharana (amulet) - trivrut manidharana by garbhini stree has been mentioned by Acharya Kashyapa which also owns anti-viral properties.

- Rakshogha dravya dhupana - use of rakshogna dravya in sutikagara has been mentioned by the Acharyas. Dhupana of rakshogna dravyas like guggulu (Commiphora mukul), nimba (Azadiracta indica), hingu (Ferula foetida) has antiviral properties and thus, helps in sanitization, purification and disinfection of sutikagara as well as helps in treating diseases such as cold, fever and graha doshas. Almost all the rakshogna dravyas have antiseptic, insecticidal, anti-pyretic and anti-inflammatory properties.

- Devathacharana - by performing yajna and yaaga we can tackle the communicable diseases because the drugs offered during yajna like haridra (Curcuma longa), apamarga (Achyranthes aspera), vidanga (Embelia ribes), kushta (Saussurea lappa), devadaru (Cedrus ) etc owns krimigna property. It will work like a natural purifier of air through which we can avoid droplet infections of air.

Acahara rasayana - out of various types of rasayana, achara rasayana is a unique nonpharmacological therapy which comprises of wholesome diet, ideal lifestyle, etiquettes to be followed by a person at social level with all the benefits described for the rasayana. Due to its effects on improving immunity, rasayana therapy may have direct relevance in the prevention and management of SARS COVID infection. Acharya Charaka in chikitsa sthana $1^{\text {st }}$ chapter described achara rasayana which indicates its importance to keep the disease away from humanity. Achara means following good discipline or doing behaviour modification for a healthy life. Proper implementation of these principles results in the dhatu samya (equilibrium of dhatus) which is the ultimate aim of Ayurveda. For instance:

- Satyavadinam - when patient tries to hide the history of contact, it might aid in the spread of the disease.

- Shoucha param - in corona outbreak maximum importance is given to personal hygiene interms of hand washing, social distancing, wearing face mask. The same can be correlated with shoucha param.

Achara rasayana helps the individual in understanding the society and to know the role of individual in the society. Recommendations of WHO and MHA guidelines in controlling the pandemic of COVID-19 have close resemblance with the principles explained in achara rasayana.

- Yogasana - Yoga is one way which can naturally uplift vitality. However, the benefits of yoga are not just limited to stress relief and mental wellness but also can recharge the body, get rid of the toxins, and keep the vital organs functioning properly. Certain yogasanas can help support, balance and boost the immune system. Yoga reduces stress 


\section{EPRA International Journal of Research and Development (IJRD) \\ Volume: 6 | Issue: 10 | October 2021 \\ - Peer Reviewed Journal}

systemically in the body, which in turn, cuts down inflammation and degeneration.

- $\quad$ Pranayama - pranayamas like nadi shodhana, brahmari, sheetali, ujjayi strengthens the immune system including pranavaha srotas.

- Avoiding garbha upaghatara bhavas like yana, advagamana also helps in preventing the disease.

- Along with this hasta parimarjana, avoiding travel and social distancing would help prevent the disease.

\section{CONCLUSION}

Ayurveda mainly focuses on an individual's health and recommends preventive measures for a healthy lifestyle rather than mere prescription of drugs. The risk and severity of infections are increased during pregnancy due to combination of physiological and immunological changes. Several general measures which are described by Acharyas are useful to reduce incidences of upcoming disease like covid-19 and complement therapeutic management as add-on treatment. By avoiding unhealthy lifestyle, adopting the geographical needs and by following the paricharya mentioned in Ayurveda, Garbhini can effectively prevent the acquired disease like SARS-CoV.

\section{REFERENCES}

1. Acharya Sushruta krita Sushruta samhita edited by Vaidya Yadavji Trikamjee Acharya, published by Chawkhamba Sanskrit sansthan Varanasi, sutra sthana $30^{\text {th }}$ chapter, $15^{\text {th }}$ shloka.

2. Ajeet Singh: Ethnobotanical pharmacological benefits and phytochemistry of soda cordifolia. International journal of pharmaceutical and clinical research, 2018, 10(1): 16-21

3. Maurya D K: Evaluation of yashtimadhu active phytochemicals against novel coronavirus. Research square Journal, 2020 May.

4. Manish Kumar Tripathi et al. Identification of bioactive molecule from Withania somnifera (Ashwagandha) as SARS-CoV-2 main protease inhibitor. NCBI, 2021 Sep.

5. Shastry J L N: volume II, $4^{\text {th }}$ edition, Varanasi: Chaumkambha orientalia, 2014, p-220

6. Samsonn Sitheni Mashele et al. Medicinal properties of selected Asparagus species. Phytochemicals in human health, 2019 March.

7. Shastry $J L N$ : volume II, $4^{\text {th }}$ edition, Varanasi: Chaumkambha orientalia, 2014, p-114 